\title{
Gesine Manuwald, Reviving Cicero in Drama: From the Ancient World to the Modern Stage, London: I. B. Tauris, $2018, x+308$ pp., ISBN 9781788312967, £85.00
}

\author{
William H. F. Altman ${ }^{1}$
}

Published online: 15 April 2019

C Springer Nature B.V. 2019, Corrected Publication 2019

The work under review is not so much a book as a numbered list, arranged in chronological order with a bare minimum of inter-connective tissue, of stage productions in which a character named 'Cicero' played a part. Of these, the most famous is Shakespeare's Julius Caesar (4.5; pp. 41-4); like all 64 others on the list, we are provided with 'Context', 'Bibliographical Information', and 'Comment.' Insight is spare in the latter, and unfortunately throughout. The work's most interesting aspect is often to be found in each play's 'Bibliographical Information' section; e.g., a Jesuit school drama entitled M. T. Cicero ab exilio redux (4.30), staged in Innsbruck on '2 and 6 September 1763', is available online (web address on p. 121) as are a surprisingly large number of other obscure texts. One regrets to disclose that the writing is at times difficult to follow; for example, the following sentence on p. 45 might sound better in German: 'Cicero is not to be characterized by a particularly literary element and is not meant to acquire much prominence.' But it is not only this kind of prose that makes the work difficult if not impossible to read, and by the time one reaches a fascinating entry like '4.60; Upton Sinclair, Cicero. A Tragedy of Ancient Rome (1960)', one's patience has long since been numbed by the recurrent format. Here there was a wonderful story to be told, and Manuwald informs us in a note (p. 287 n. 298) how she got ahold of a letter Sinclair wrote about the play that included the following gem (pp. 221-2): 'What interests me in my eighty-second year is the idea of showing students how it came about that a great republic evolved into a depraved empire'. With Shakespeare in mind, we might paraphrase the duke's question about Jacques (As You Like It, II.i.44): 'Did she not moralize this spectacle?' Answer: not so much into 'a thousand similes' as place it, accurately but without feeling, on the list. There was a labour of love to be written on this important theme, but despite the author's evident labour, it is the reader who must find this work laborious.

This Book Review has been corrected because it was initially published with an erroneous version of the book author name.

William H. F. Altman

whfaltman@gmail.com

1 Florianópolis, Santa Catarina, Brazil 